\title{
MINIMUM REINFORCEMENT FOR CRACK WIDTH CONTROL IN RC TENSILE ELEMENTS
}

\author{
M. KNAUFF ${ }^{1}$, B. GRZESZYKOWSKI ${ }^{2}$, A. GOLUBIŃSKA ${ }^{3}$
}

\begin{abstract}
New approach using direct crack width calculations of the minimum reinforcement in tensile RC elements is presented. Verification involves checking whether the provided reinforcement ensures that the crack width that may result from the thermal-shrinkage effects does not exceed the limit value. The Eurocode provisions were enriched with addendums derived from the German national annex. Three levels of accuracy of the analysis were defined - the higher the level applied, the more significant reduction in the amount of reinforcement required can be achieved. A methodology of determining the minimum reinforcement for crack width control on the example of a RC retaining wall is presented. In the analysis the influence of residual and restraint stresses caused by hydration heat release and shrinkage was considered.
\end{abstract}

Keywords: reinforced concrete, minimum reinforcement, cracking, crack control, crack width, shrinkage, hydration heat, restraint and residual stresses

\section{INTRODUCTION}

In RC elements such as long retaining walls (Fig. 1a), tank walls or other structures restrained by soil or previously casted foundation, tensile stresses resulting from the thermal - shrinkage (TS) effects can cause severe cracking. Moreover in massive elements, such as thick foundation slabs (Fig. 1b) or thick retaining walls (Fig. 1a), due to cement hydration heat release and shrinkage of concrete, the additional self-equilibrating stresses arise. In general in structures subjected to the TS

\footnotetext{
${ }^{1}$ Prof., DSc., PhD., Eng., Warsaw University of Technology, Faculty of Civil Engineering, Al. Armii Ludowej 16, 00-637 Warsaw, Poland, e-mail: mk@il.pw.edu.pl

${ }^{2}$ M.Eng., Warsaw University of Technology, Faculty of Civil Engineering, Al. Armii Ludowej 16, 00-637 Warsaw, Poland, e-mail: bgrz@il.pw.edu.pl

${ }^{3}$ PhD., Eng., Warsaw University of Technology, Faculty of Civil Engineering, Al. Armii Ludowej 16, 00-637 Warsaw, Poland, e-mail: ag@il.pw.edu.pl
} 
effects, the stress state can be described as a sum of the linear restraint and nonlinear residual stresses, as depicted in Fig. 1c. The restraint stresses depend highly on the boundary conditions of the structure subjected to tension caused by the TS effects. On the other hand the residual stresses, both those that originate from the hydration heat release and those caused by drying shrinkage, do not depend on the static scheme of the structure, because they do not cause any deformation of the whole element. Various methods for calculating the TS stresses can be found in [1], [2], [3], [4].

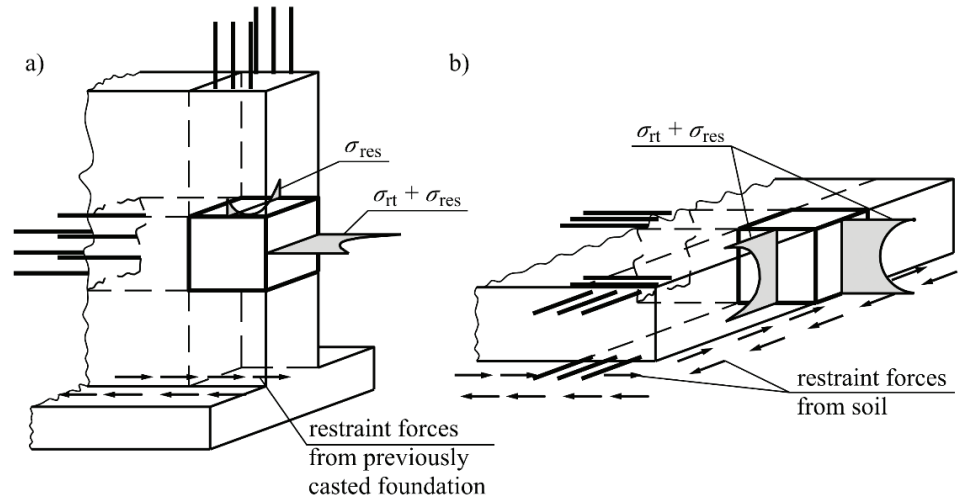

c)

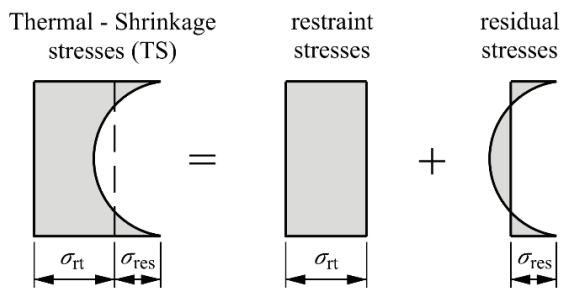

Fig. 1. Restraint and residual stresses in a: a) wall, b) slab foundation; c) the thermal-shrinkage stresses (TS) as the sum of restraint and self-equilibrating residual stresses

In standard [5] the minimum reinforcement for crack width control in restrained concrete members is based on the simplified calculations taking up the cracking force of the cross section. This concept gives straightforward results but its consistent application can have a decisive influence on the amount of required reinforcement and usually leads to a very high steel consumption, especially for thick elements. Regulations from [5] regarding the minimum reinforcement for the crack width control (hereafter this reinforcement will be called $\mathbf{m i n}_{\boldsymbol{c r}}$ ) refer only to the bar elements. Therefore to apply those rules to plates or walls, imaginary tensile bar elements have to be separated from the structure just like in the design with strut and tie models. 
The general principle for $\mathbf{m i n}_{c r}$ in standard [5] was is given by:

"7.3.2.1(P). If crack control is required, a minimum amount of bonded reinforcement is required to control cracking in areas where tension is expected. The amount may be estimated from equilibrium between the tensile force in concrete just before cracking and the tensile force in reinforcement at yielding or at a lower stress if necessary to limit the crack width."

The minimum reinforcement determined for the stress in steel equal to the yield strength is by definition the minimum reinforcement for the ultimate limit state (minuls). The minimum reinforcement for the crack width control usually must be determined for significantly lower stress level. For the crack width to stay within the limit, the reinforcement must remain elastic after the cracking occur and therefore the crack width will decrease after unloading. Under such circumstances the cracking is under control. It is worth noting that according to the standard [5], the $\min _{c r}$ have to be applied to all areas where tension may occur regardless of the value of tensile stress. Reinforcement smaller than $\mathbf{m i n}_{c r}$ can be designed only in areas exclusively under compression. This is a fundamental element of the doctrine of the norm [5], but if tension arise from the restrain of the TS deformations - and this is the case for almost any structure - the consistent application of the Eurocode's regulations can lead to high reinforcement amounts. However in standard [5] a numerous examples of provisions inconsistent with the general rules of determining $\min _{\boldsymbol{c} r}$ mentioned above can be found. For example in RC slabs not thicker than $200 \mathrm{~mm}$ subjected to bending without significant axial tension, specific measures to control cracking, and therefore $\min _{c r}$, are not necessary. Further discussion about exceptions to the principle regarding $\mathbf{m i n}_{c r}$ can be found in [3].

In the opinion of the authors, the principle of the $\mathbf{m i n}_{c r}$ should be considered useful because it emphasizes the need for taking into account important phenomena such as TS effects in concrete, often disregarded in the design process. However in cases where the tensile stresses are small, simplified calculations taking up the cracking force of the cross section usually lead to a very high steel consumption, especially in thick elements. On the other hand, considering the random nature of the TS effects in concrete, in cases where crack control is required the minimal reinforcement is necessary.

The article presents the authors' concept regarding the calculations of the minimum reinforcement for crack width control in RC tensile elements, especially in cases in which tension occurs due to the TS effects. The concept was based on the Eurocode 2 [5] enriched with addendums derived from the German national annex [6], that allowed to calculate the reinforcement for stresses smaller than the tensile strength. 


\section{MINIMUM REINFORCEMENT FOR CRACK WIDTH CONTROL}

\subsection{BASIC ASSUMPTIONS OF THE EUROCODE 2}

The minimum reinforcement for crack width control in axially tensioned elements is determined by the formula

$$
N_{c r}=k f_{c t, e f f} A_{c}=A_{s} \sigma_{s} \rightarrow A_{s}=k f_{c t, e f f} \frac{A_{c}}{\sigma_{s}}
$$

where $N_{c r}$ is the cracking force, $A_{s}$ is the amount of $\min _{c r} ; A_{c}$ is the area of concrete cross section; $f_{c t, \text { eff }}$ is the effective tensile strength of concrete; $\sigma_{s}$ is the stress in steel after the cracking and $k \leq 1$ is the coefficient which reduces the cracking force due to the self-equilibrating residual stresses that arise from TS effects (Fig. 1c). Eq. (2.1) is based on the basic assumption that maximum tensile stress in the cross section immediately before cracking is equal to the effective tensile strength $f_{c t \text {,eff. }}$ After the cracking concrete is only the matrix for the bonded reinforcement and does not transfer any forces. The amount of $\mathbf{m i n}_{\boldsymbol{c}}$ is estimated from equilibrium between the force in concrete just before cracking and the force in the reinforcement immediately after the cracking.

The effective concrete tensile strength $f_{c t \text {, eff }}$ is the value of the tensile strength of the concrete effective at the time when the cracks may first be expected to occur. It has a strong influence on the amount of $\boldsymbol{m i n}_{\boldsymbol{c}}$. The effective tensile strength concept corrects the value of the tensile strength of concrete to account for the influence of the concrete's age. If cracking occurs in a fresh concrete, a smaller value than the mean tensile strength of concrete $f_{c t m}$ can be assumed. Unfortunately in the design code [5] no more information are included. According to [6], when the cracking occurs a few days after casting primarily due to the cement hydration heat release, $f_{c t \text {, eff }}=0.5 f_{c t m}$ may be assumed, what leads to significant savings in the amount of the reinforcement. However, if $\mathbf{m i n}_{\boldsymbol{c} r}$ is needed due to effects that can occur after the concrete attain expected strength, then $f_{c t \text {, eff }}=f_{c t m}$, which leads to a very high reinforcement amounts.

The reduction coefficient $k$ is the coefficient which allows for the effect of non-uniform residual self-equilibrating stresses that can occur due to the non-uniform temperature distribution during the hydration heat release process and the differential drying shrinkage. The residual stresses cause that the element cracks at an average value of the tensile stress smaller than the effective

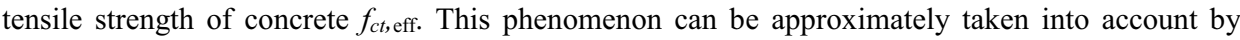
assuming the reduced concrete tensile strength (multiplied by the coefficient $k \leq 1$ ) or reducing the cross-sectional area of the tensile zone by multiplying it by this factor. In thick RC elements 
irregularities in the hydration heat release are higher in comparison to thin cross-sections, therefore for such elements the values of $k$ will be smaller. The essence of the problem is illustrated in Fig. 2. As a result of the cement hydration heat release, at the surfaces of the cross-sections tensile residual stresses arise. If the deformations of the element are restrained, additional approximately uniform restraint tensile stresses appear. After the tensile stress on the surfaces of the element reach the effective tensile strength of concrete $f_{c t \text {, eff, }}$ cracking occurs. Stresses near the surfaces of the cracked cross-section disappear. It is assumed that in the central part of the cracked cross-section the stresses in the concrete are equal to $f_{c t \text {, eff }}$ and therefore in cross-sections between the cracks the

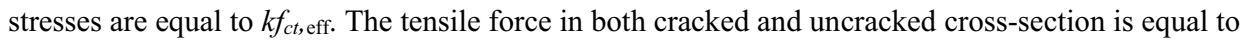

$$
N=N_{c r}=-\left(k A_{c}\right) f_{c t, e f f}=-A_{c}\left(k f_{c t, e f f}\right)
$$

a)
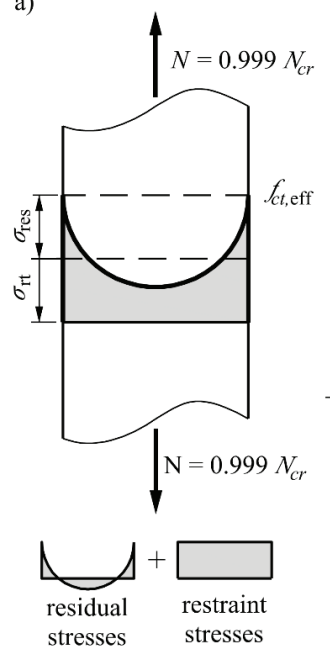

b)

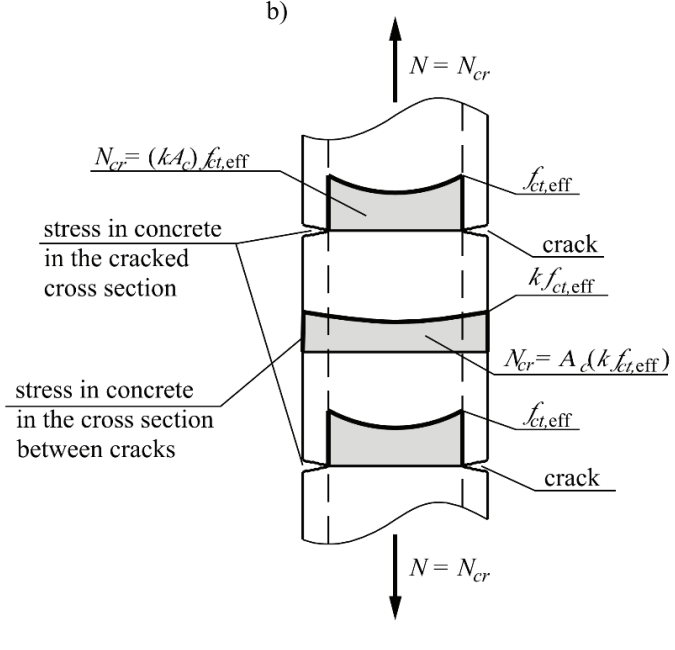

Fig. 2. Residual and restraint stresses a) just before and b) just after cracking.

The above principle used in the standard [5] is consistent with the general principle of calculating reinforced concrete structures. Static calculations are performed for uncracked elements without reinforcement (the value of force $N$ is determined this way) and then the design of the reinforcement is carried out based on the theory valid for cracked elements loaded with the force $N$. In [5] the value of the $k$ coefficient is defined as follows:

$k=1.0$ for webs with $h \leq 300 \mathrm{~mm}$ or flanges with widths less than $300 \mathrm{~mm}$, $k=0.65$ for webs with $h \leq 800 \mathrm{~mm}$ or flanges with widths greater than $800 \mathrm{~mm}$. 
Intermediate values may be interpolated. Instead of those not very clear guidelines, the authors propose for the value of the $k$ coefficient to be determined from the Fig. $4 \mathrm{~b}$ based on [6].

In Fig. 3 the loading and unloading response of a reinforced tensile member assumed in the standard [5] is shown. The bilinear relationship between the average stress and strain in the cracked element against the two lines representing the phase I (uncracked cross-section) and phase II (cracked cross-section) is depicted. The bilinear relationship was determined using the general method of the calculation of crack width from the paragraph 7.3.4 of the standard [5] and can also be used for $N<N_{c r}$. Under monotonic loading, the behaviour of the element can be described using the line representing the phase I $(0 \mathrm{~A})$. After reaching the cracking force (in Fig. 3 it is assumed that $f_{c t \text {, eff }}=0.5 f_{c t m}$ ), a transition to the bilinear relationship occurs. At that point, the member enters in the crack development stage (approximated by a horizontal line $\mathrm{AB}$ ) where cracks are created. Afterwards the number of cracks remains constant but their openings increase with the load (CD). This phase ends with the yielding of the reinforcement. From that point, both for loading and unloading of the element, the strain is computed from the bilinear relationship which allows for determining the strains and the crack width in RC elements subjected to any tensile forces, even smaller than the cracking force $N<N_{c r}$. This issue is of fundamental importance in determining the minimum reinforcement for the crack width control $\mathbf{m i n}_{c r}$. As shown in Fig. 3, in standard [5] it is assumed that once the cross-section is cracked, both loading and unloading occurs at the same loading path. This leads to a zero-width cracks in the completely unloaded element. However in [7] it is stated, that the complete unloading of a tensile member leads to a residual strain and crack width. This shows that calculating the response of a tension member using a monotonic loading pattern may underestimate the actual value of the crack width for elements under cyclic loading. The crack width in such elements may increase with each cycle.

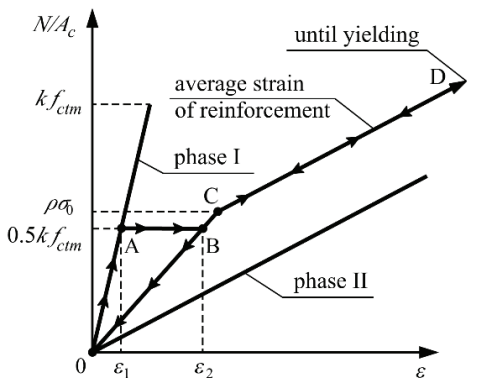

Fig. 3. Relationship between the average stress and the average strain in RC element under axial tension 
The minimum reinforcement for crack width control is by definition the reinforcement, for which the crack width, determined for the cracking forces (or smaller, see the next paragraph), is equal to the limit value. Rules and equations governing the crack width calculations in standard [5] are rather complicated and to efficiently calculate such reinforcement a computer is needed, therefore in the standard [5] the Eq. (2.1) was introduced. However in the opinion of the authors the computers are nowadays widely available to engineers therefore authors propose to calculate the $\min _{c r}$ directly by definition, for example using spreadsheet included with the book [3] or simply using custom made spreadsheets.

\subsection{ADDENDUMS TO THE EC 2 DERIVED FROM THE GERMAN NATIONAL ANNEX}

German National Annex [6] contains several important addendums to the European standard [5]. Firstly, in the paragraph NCI Zu 7.3.2(2)) of [6] it is written (author's translation from in German): "If the imposed internal forces do not reach the values of the cracking forces, the minimum reinforcement may be reduced. In such cases the minimum reinforcement should be determined by the design of the cross-section loaded with the computed imposed forces, taking into account the crack control requirements"

The above addendum is of fundamental importance because in cases where the tensile stress are small it allows to give up calculations taking up the cracking force of the cross section and therefore to potentially lower the steel consumption. It will be called the first German addendum.

The second German addendum is important in the design of thick elements, in which the residual stresses have a significant influence on cracking. In [6] it is assumed, that the residual stresses are transmitted through the effective areas near the surfaces of the element (Fig. 4a). In the element of the width $b$ (for slabs $b=1.0 \mathrm{~m}$ ), the effective area is equal:

$$
A_{\text {eff }}= \begin{cases}5 b a_{1} & \text { for } h / a_{1} \leq 5 \\ 4 b a_{1}+0.2 b h & \text { for } 5<h / a_{1}<30 \\ 10 b a_{1} & \text { for } h / a_{1} \geq 30\end{cases}
$$

and the effective cracking force can be computed using the Eq. (2.4).

$$
N=N_{c r}=-f_{c t, \mathrm{eff}} A_{\text {eff }}
$$

The Eq. (2.4) is an alternate to Eq. (2.2) method of calculating the cracking force of the crosssection. On analyzing the Eq. (2.3) it can be concluded, that as thick may be considered elements in 
which $A_{c}>A_{\text {eff. In }}$ thin elements, the effective area $A_{\text {eff }}$ is equal to the total area of the cross-section $A_{c}$.

b)
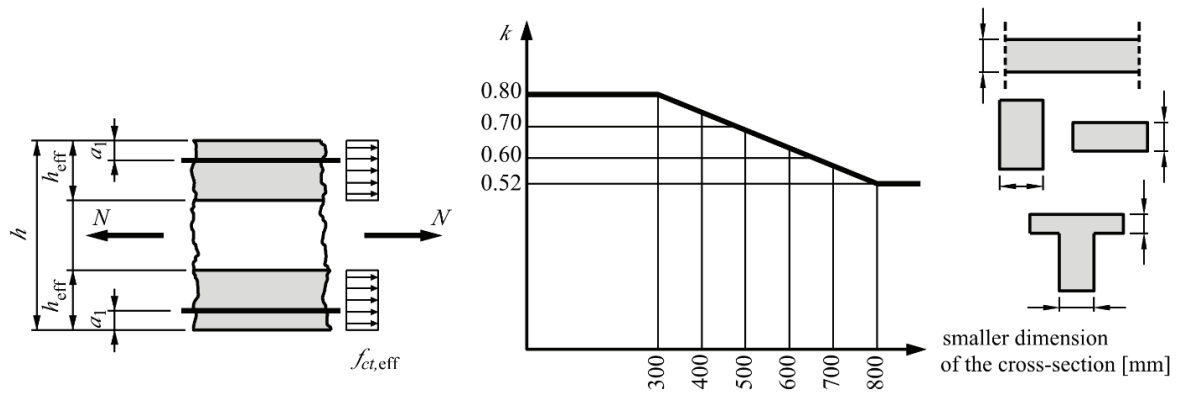

Fig. 4. a) The effective cross-sectional area in thick elements and b) the coefficient $k$, according to [6]

The third German addendum concerns the simultaneous actions of imposed and direct loading. When calculating the crack width caused by simultaneous effects of the TS imposed tensile stresses and other loads the same rules and formulas apply. The strains caused by the direct loading should be increased by the values resulting from the imposed forces. However, if the strain (computed assuming that the element is cracked) resulting from the imposed deformations does not exceed $0.8 \%$ o (therefore the stress in steel does not exceed $160 \mathrm{MPa}$ ), it may be sufficient to calculate the crack width for the greater of the two.

In the fourth German addendum it is recommended to determine the value of the $k$ coefficient from the Fig. $4 \mathrm{~b}$ instead of not very clear guidelines from [5].

\section{TWO CRITICAL TERMS}

The restraint and residual tensile stresses may arise due to either thermal or shrinkage strain. In the first critical term a key role plays the thermal effects and in the second critical term a shrinkage induced strain is of the greatest significance. Regardless of the origin of the strain, restraint tensile forces may arise only when the deformations of the element are restrained. For slab foundations the restraint factor may be the soil (Fig. 1b) and for retaining or building walls, the deformations may be limited for example by the previously casted foundation (Fig. 1a). In RC slabs the restraint may be caused by columns and building or stairwell walls. A contraction joints may lower thermal induced strain in the first critical term but obviously they are ineffective for the shrinkage induced strain in the second critical term. Construction and/or contraction joints are effective against both 
thermal and shrinkage effects. Residual stresses, both those that originate from the hydration heat release and those caused by differential drying shrinkage are self-equilibrated and do not cause any global deformation of the element, therefore they are independent on the boundary conditions of the structure.

\subsection{FIRST CRITICAL TERM}

The first critical term occurs a few days after casting, when the concrete can be considered as fresh and yet hardened enough to crack. The high temperature of the element induced by the hydration heat release decreases and at the outer surfaces of the element (colder than the inside), residual tensile stresses arise. The problem of determining the temperature field due to the hydration heat release is a subject of many publications [8], [9], [10], [11], [12], [13]. Because of its relative simplicity, in this paper the parabolic distribution of temperature (Fig. 5a) and residual stresses (Fig. $5 b$ ), following [1] is assumed. With this assumption, the stress distribution is also parabolic and, assuming linear elastic material, the difference between the tensile stress at the surface of the element and the stress in the middle is proportional to the difference of temperatures $T_{\text {int }}-T_{s}$ and equal

$$
\Delta \sigma_{c}=\alpha_{t} E_{c}\left(T_{\mathrm{int}}-T_{s}\right)
$$

where $\alpha_{t}$ is a thermal expansion coefficient of concrete.

The residual tensile stress on the edge of the element $\sigma_{r e s}$ is equal $2 / 3 \Delta \sigma_{c}$ (Fig. 5b). The resultant force of the tensile residual stress, assuming its triangle distribution (Fig. 5c) is equal $2 \cdot 0,5 \cdot 0,211 \cdot h b \sigma_{\text {res }}=0,211 A_{c} \sigma_{\text {res. }}$. Given the arbitrary nature of the simplifying assumptions and the uncertainty of the input data it was assumed that the resultant tensile force can be calculated from the conservative formula

$$
N_{\text {res }}=0.3 A_{c} \sigma_{\text {res }}
$$

in the case depicted in Fig. 5d, where it is assumed that the stress in the entire tension zone is equal to $\sigma_{\text {res }}$ (upper estimate) the resultant force is equal $2 \cdot 0,211 \cdot h b \sigma_{\text {res }}=0,422 A_{c} \sigma_{\text {res. }}$ In the opinion of the authors the residual stresses caused by the differential drying shrinkage are of lesser importance in the first critical term due to their smaller values in comparison to those that originate from the hydration heat release and can be omitted in the analysis. The restraint stresses, assuming linear elastic material and equal ambient and initial temperature of the element, are proportional to the difference of average and ambient temperature $T_{m}-T_{a}$, which can be used as an input to calculate 
the restraint forces for example using FEM software. The formulas for the temperature field variables presented in Fig. 5a can be found in [1]. Those formulas are also implemented into the spreadsheet attached to [3].

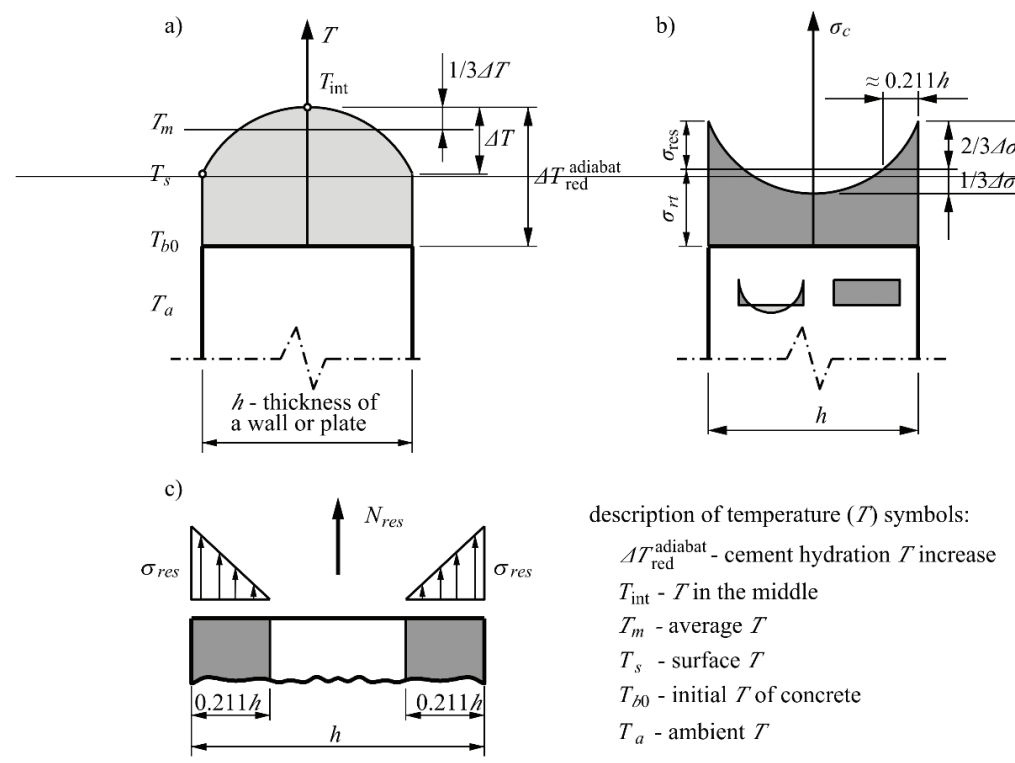

Fig. 5. a) Temperature and b) stress distribution in a RC wall (plate) caused by the cement hydration heat release [1]; c) triangle approximation of residual tensile stress distribution.

\subsection{SECOND CRITICAL TERM}

The second critical term occurs much later, when the compensation of the temperature is completed and the concrete already achieved its design strength. Residual and restraint stresses caused by the hydration heat release are no more relevant. In the second term the reason for cracking are primarily the shrinkage induced restraint forces accompanied by the residual stresses caused by a differential drying shrinkage (the outer layers of the slab dry faster than the inside of the element). Predictions of the differential drying shrinkage in concrete members can be found in [14], [15], [16].

In Annex B to the standard [5], the basic equations for determining the drying shrinkage strain $\varepsilon_{c d}(t)$ under constant ambient conditions can be found. However the ambient relative humidity $R H$ and the notional size of the member $h_{0}$ may change during the relevant period of time (e.g. due to removal of the framework). In order to obtain the final shrinkage strain $\varepsilon_{c d}(t)$, the authors propose to perform the superposition of the shrinkage functions, the concept well known from the 
creep theory and used to calculate the creep strain at varying stresses. In Fig. 6a the procedure for computing the total shrinkage strain of a single element for three periods of time with varying conditions is presented. In Fig. $6 \mathrm{~b}$ a procedure for determining the shrinkage strain for two elements (in this case the wall on a previously casted foundation) casted with a certain time offset is shown. If the element 1 is casted before the element 2 then the effective shrinkage strain causing the imposed stresses is the difference between the shrinkage strain of the element 1 and 2 . The longer the delay in casting the second element, the greater the difference of shrinkage strain. The maximum effective shrinkage strain can be used as an input to calculate the restraint forces for example using FEM software, where the shrinkage strain can be represented as a temperature reduction.

When the calculations show that the element will crack in the first critical term, then the calculations in the second critical term may usually be skipped. This is due to the fact that the stresses caused by the imposed deformations depend not only on the boundary conditions of the structure but also on its stiffness. And as a result of cracking the stiffness of the element will decrease and it is highly unlikely that the shrinkage imposed stresses will exceed those that will arise under the influence of the cracking force determined for $f_{c t, \text { eff }}=0.5 f_{c t m}$ in the first critical term. If the structure is not cracked due to the hydration heat release, the calculations in the second critical term must be performed and the amount of $\min _{c r}$ in the cracked regions may be substantial because $f_{c t \text {,eff }}=f_{c t m}$.

In the second critical term the shrinkage tensile stresses may coexist with other loads, which in practice can reduce the effects of the shrinkage in concrete, what was depicted in Fig. 7. For example in a building basement wall casted on a foundation with the time offset of weeks, after couple of months (or years) shrinkage induced stresses may be of a maximum value close or equal to the cracking force $N_{c r}=A_{c} f_{c t m}$. However in the same wall the additional compressive stresses arise preventing the cracking of concrete. This is due to the shrinkage of the floor slab above, for which the considered wall is a restraint itself (Fig. 7). Moreover other transverse stiffening walls, next floor beams, slab and the foundation itself provide the stiffening system which limits the horizontal deformation capacity of the wall and therefore induce yet additional compressive stresses $\sigma_{x}$ originated from the gravity loads $\sigma_{z}$ from the floors above (Fig. 7). Therefore it can be concluded that in cases of relatively tall buildings, the $\mathbf{m i n}_{\boldsymbol{c}}$ designed in the first critical term for the thermal effects may be sufficient even if the wall was not cracked during this period - further calculations including the shrinkage induced strain may not be necessary in that case. However for walls not subjected to gravity loads from the floors above (low-rise buildings, retaining walls), shrinkage 
induced restraint of deformations may be of a greatest significance, especially in cases where the cracking of concrete did not occur in the first critical term.

a)
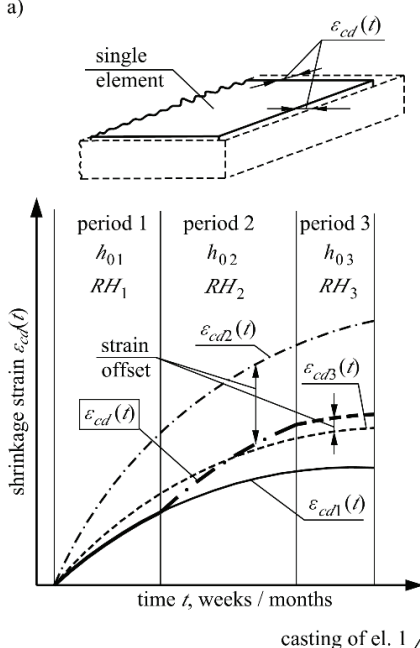

b)

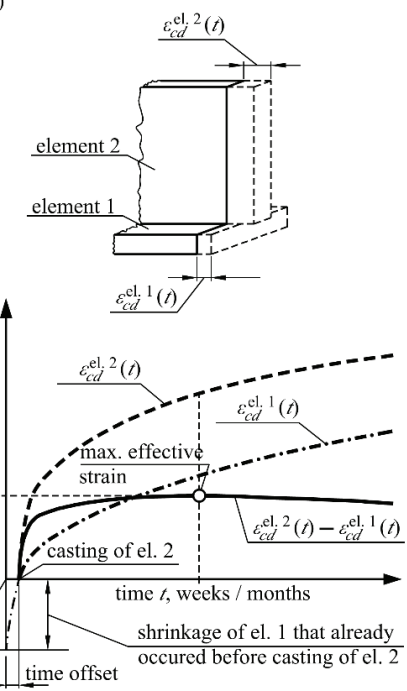

Fig. 6. Determination of a): a drying shrinkage strain in single element under varying ambient conditions;

b) the effective shrinkage strain in two elements casted with the time offset

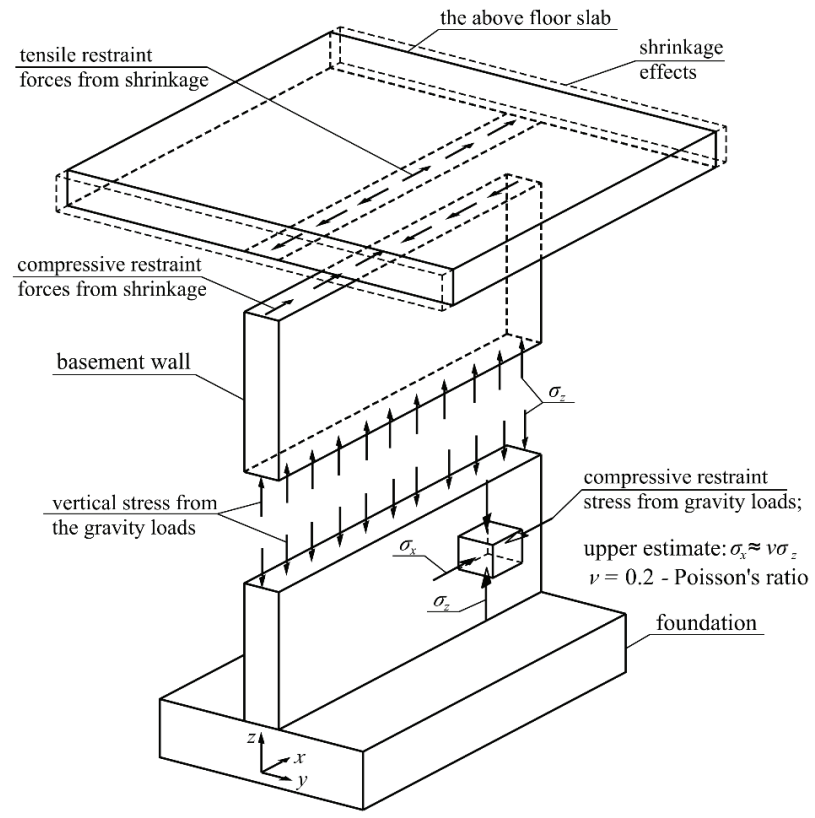


Fig. 7. Additional compressive restraint stresses preventing the cracking of the building foundation wall in the second critical term.

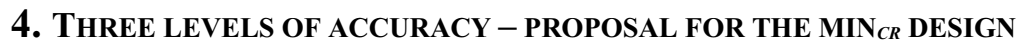

The minimum reinforcement for crack width control $\mathbf{m i n}_{c r}$ is by definition the reinforcement, for which the crack width computed for the tensile force $N$ is equal to the maximum admissible value. The effective tensile force $N$ can be determined using two levels of accuracy. The procedure of determining $\min _{c r}$ in the entire element for the cracking force only, $N=N_{c r}$, will be called the basic level of accuracy (level 0 ). If the effective cracking force $N_{c r}$ is determined using the Eq. (2.2) in which the $k$ coefficient is determined from Fig. 4, then this procedure will be called the Eu0 method. However, if the effective cracking force $N_{c r}$ is determined using the Eq. (2.4), then this procedure will be called the Eu0n method. For thick elements, the Eu0n method can lead to smaller amounts of $\mathbf{m i n}_{\boldsymbol{c}}$ in comparison to Eu0 method. Both methods are called level 0 methods, because they rely only on calculations taking up the cracking force of the cross-section and can be used without computing any TS imposed stresses. In the first critical term it can be assumed that $f_{c t \text {, eff }}=0.5 f_{c t m}$ and in the second $f_{c t \text {, eff }}=f_{c t m}$. Moreover from such basic calculations any conclusions regarding the reinforcement distribution and the influence of the contraction joints (in the first critical term) and construction joints (in both critical terms) on the amount of $\mathbf{m i n}_{\boldsymbol{c}}$ cannot be drawn.

More advanced first level of accuracy methods require calculating the TS stresses in both critical terms, for example using FEM software. A procedure in which the distribution of the effective tensile force $N$ is determined assuming concrete as a linear elastic material will be called the Eu1 method. It is consistent with the general principle used for RC structures - the static calculations are performed for uncracked elements without any reinforcement and then the design of the reinforcement is carried out for cracked elements. The results of such calculations depend on the cement class (S, N or R) and on the number and placement of the joints. The results also contain information regarding the stress distribution in the structure and therefore allow to decrease, thanks to the first German addendum, the amount of reinforcement in areas where the tensile stresses are smaller.

In Fig. 8a an example of a retaining wall FEM model that can be used in Eu1 calculations is shown. The slab foundation modeled with solid elements lays on an elastic Winkler's foundation and the wall is made of shell elements. The only acting loads on the structure are the self-weight, 
thermal loading (in the first critical term) and the maximum effective shrinkage strain (in the second critical term). In Fig. 8b the typical normal stress distributions in a short segment are depicted. In Fig. $8 \mathrm{c}$ the stresses in a long retaining wall are shown.

a)
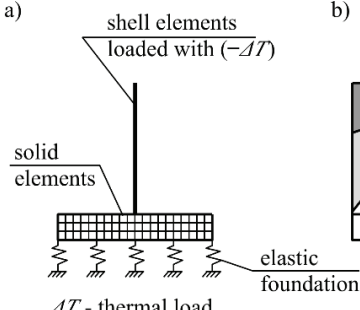

$\Delta T$ - thermal load

b)

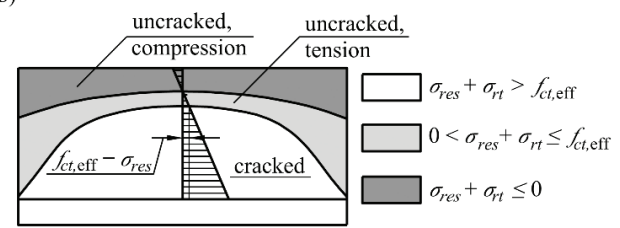

c)

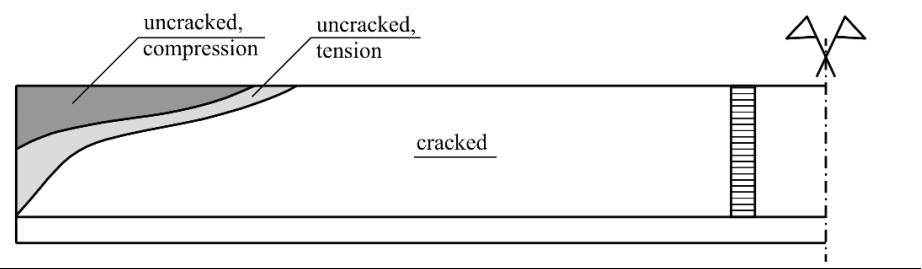

Fig. 8. A retaining wall: a) FEM model description; typical normal horizontal stress distribution in: b) short segment, c) long segment, half is shown

a)

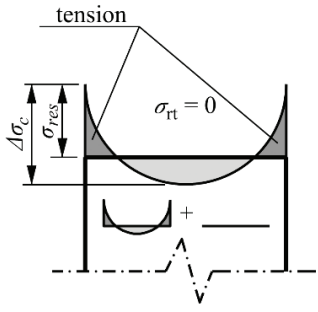

c)

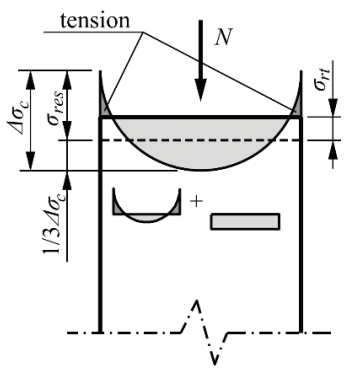

b)

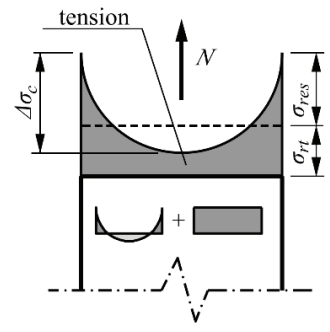

d)

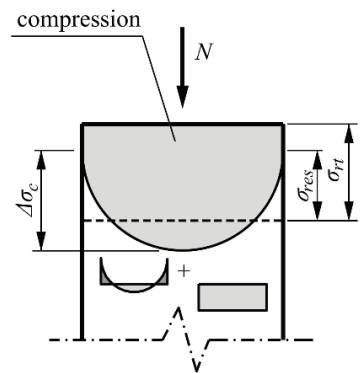

Fig. 9. Superposition of restraint and residual stresses for a) $\sigma_{r t}=0$; b) $\sigma_{r t}>0$; c) $\sigma_{r t}<0$ i $\left|\sigma_{r t}\right|<\left|\sigma_{r e s}\right|$, d) $\sigma_{r t}<0 \mathrm{i}\left|\sigma_{r t}\right|>\left|\sigma_{r e s}\right|$; tensile stress is positive 
The white color distinguish areas where the tensile restraint and residual stresses superpose and cause the cracking of concrete (Fig. 9b). In those areas the $\mathbf{m i n}_{c r}$ can be computed using the Eu0 or Eu0n methods. In the light-gray areas the restraint stresses $\sigma_{r t}$ are smaller than the effective concrete tensile strength $f_{c t \text {,eff }}$ diminished by the residual tensile stress on the surface of the wall $\sigma_{\text {res }}$. Therefore the concrete is not cracked and according to the first German addendum and Eq. 3.2, in those areas the effective tensile force is equal $N=-A_{c}\left(0.3 \sigma_{r e s}+\sigma_{r t}\right)$. In the dark-gray areas the restraint stresses are compressive (Figs. $9 \mathrm{c}$ and d) therefore the conservative approach is to design the $\min _{c r}$ only for residual stresses and assume the effective tensile force equal to $N=-0.3 A_{c} \sigma_{\text {res }}$ in computing the crack width (Fig. 9a). A summary of all the above options is presented in the Tab. 1.

Tab. 1. Design conditions for $\mathbf{m i n}_{c r}$

\begin{tabular}{|c|c|c|c|}
\hline Region & Condition & $\begin{array}{l}\text { Sign of the resultant } \\
\text { stress on the surface }\end{array}$ & $\begin{array}{c}\text { Design force for } \mathbf{m i n}_{c r} \\
\left(f_{c t, \text { eff }}-\sigma_{r e s}\right)=\text { cracking stress }\end{array}$ \\
\hline $\begin{array}{l}\text { cracked } \\
\text { (white) }\end{array}$ & $\sigma_{r t}>f_{c t, \mathrm{eff}}-\sigma_{r e s}$ & tension & $\begin{array}{c}N=-k f_{c t, \text { eff }} A_{c}[\mathrm{Eu} 0] \text { or } \\
N=-f_{c t, \text { eff }} A_{\text {eff }}[\mathrm{Eu} 0 \mathrm{n}]\end{array}$ \\
\hline $\begin{array}{l}\text { uncracked } \\
\text { (light gray) }\end{array}$ & $\sigma_{r t} \leq f_{c t, \mathrm{eff}}-\sigma_{r e s}$ & tension & $N=-A_{c}\left(0.3 \sigma_{r e s}+\sigma_{r t}\right)$ \\
\hline $\begin{array}{c}\text { uncracked } \\
\text { (dark gray) }\end{array}$ & $\sigma_{r t} \leq \sigma_{r e s}$ & compression & $\begin{array}{c}\min _{c r} \text { only for residual stresses } \\
\qquad N=-0.3 A_{c} \sigma_{r e s}\end{array}$ \\
\hline
\end{tabular}

\subsection{SECOND LEVEL OF ACCURACY}

The simplest calculations that can be performed using nowadays widely available FEM software are based on the assumption commonly used in static calculations, that RC elements are uncracked and built from elastic materials. Improved methods take into account inelastic properties of the materials, especially the effect of stiffness degradation caused by cracking of concrete. This more advanced calculations, example of which can be found in [17], [18], [19], [20], [21] are not the subject of this paper.

\section{Conclusions}

In RC concrete elements, the temperature changes related to the exothermic nature of cement hydration and the shrinkage of concrete may cause indirect interactions resulting in severe cracking. In the first critical term the thermal induced imposed strain plays a key role in the hardening concrete. In the second critical term a shrinkage induced strain may be of the greatest significance 
in hardened structure. New approach in determining the minimum reinforcement for crack width control, using direct crack width calculations in tensile RC elements is presented. The minimum reinforcement determined for the crack width to be equal to the maximum allowable value, computed according to the general rules of standard [5] (other standards and methods can also be used) is by definition the minimum reinforcement for the crack width control $\left(\mathbf{m i n}_{c r}\right)$. Three levels of accuracy of the analysis were defined. In the basic level calculations (Level 0), the calculations are performed by taking up the cracking force of the cross-section. At the higher level of accuracy (Level 1), thanks to modifications to the standard [5] taken from the German national annex [6] which allow to give up calculations taking up the cracking force, the amount of $\boldsymbol{m i n}_{c r}$ can be reduced. In areas where the tensile stresses are smaller, the crack width can be computed for TS stresses determined using linear-elastic FEM models. In the opinion of the authors the level 1 methods give a reasonable, scientifically based compromise to the calculations of $\mathbf{m i n}_{\boldsymbol{c r}}$ and gives the designers a relatively simple tool to take into account the TS effects. A methodology of determining the minimum reinforcement for crack width control in a $\mathrm{RC}$ retaining wall is presented. Calculations was performed using nowadays widely available engineering software.

\section{REFERENCES}

1. K. Flaga, B. Klemczak, "Konstrukcyjne i technologiczne aspekty naprężeń termiczno-skurczowych w masywnych i średniomasywnych konstrukcjach betonowych", 2016.

2. W. Kiernożycki, "Betonowe konstrukcje masywne: teoria, wymiarowanie, realizacja", Polski Cement, 2003.

3. M. Knauff, B. Grzeszykowski, A. Golubińska, "Przykłady obliczania konstrukcji żelbetowych. Zeszyt 3. Zarysowanie", Warszawa, PWN, 2018.

4. ACI Committee, "Prediction of Creep, Shrinkage, and Temperature Effects in Concrete Structures", 1982.

5. CEN, EN 1992-1-1:2008 - Eurocode 2, Design of concrete structures - Part 1-1 : General rules and rules for buildings, 2008.

6. DIN, EN 1992-1-1/NA, Nationaler Anhang - National festgelegte Parameter - Eurocode 2: Bemessung und Konstruktion von Stahlbeton und Spannbetontragwerken - Teil 1-1: Allgemeine Bemessungsregeln und Regeln für den Hochbau, 2011.

7. A. Muttoni, R. M. Fernández, "Concrete cracking in tension members and application to deck slabs of bridges", Journal of Bridge Engineering, 12(5): pp 646-653, 2007.

8. M. Nobuhiro, U. Kazuo, "Nonlinear thermal stress analysis of a massive concrete structure", Computers \& Structures, 26(1-2): pp 287-296, 1987.

9. Portland Cement Association, "Portland cement, concrete, and heat of hydration", Concrete Technology Today, 18(2): p. 1-4, 1997.

10. J. K. Kim, H. K. Kim, J. K. Yang, "Thermal analysis of hydration heat in concrete structures with pipe-cooling system", Computers \& Structures, 79(2): pp 163-171, 2001.

11. K. B. Park, N. Y. Jee, I. S. Yoon, H. S. Lee, "Prediction of temperature distribution in high-strength concrete using hydration model", ACI Materials Journal, 105(2): pp 180, 2008.

12. Z. Yunchuan, B. Liang, Y. Shengyuan, C. Guting, "Simulation analysis of mass concrete temperature field", Procedia Earth and Planetary Science, 5: pp 5-12, 2012.

13. B. Kuriakose, B. N. Rao, G. R. Dodagoudar, "Early-age temperature distribution in a massive concrete foundation", Procedia Technology, 25: pp 107-114, 2016.

14. J. K. Kim, C. S. Lee, "Prediction of differential drying shrinkage in concrete", Cement and Concrete Research, 28(7): pp 985-994, 1998. 
15. C. de Sa, F. Benboudjema, M. Thiery, J. Sicard, "Analysis of microcracking induced by differential drying shrinkage", Cement and Concrete Composites, 30(10): pp 947-956, 2008.

16. H. Samouh, E. Rozière, A. Loukili, "The differential drying shrinkage effect on the concrete surface damage: Experimental and numerical study", Cement and Concrete Research, 102: pp 212-224, 2017.

17. J. Bödefeld, "Rissmechanik in dicken Stahlbetonbauteilen bei abfließender Hydratationswärme", Beiträge zum Doktorandensymposium 2010-51, Forschungskolloquium, Beton-Werkstoff der Superlative, 11.-12: pp 757$768,2010$.

18. B. Klemczak, "Modeling thermal-shrinkage stresses in early age massive concrete structures-Comparative study of basic models", Archives of Civil and Mechanical Engineering, 14(4): pp 721-733, 2014.

19. D. Schlicke, N. V. Tue, "Minimum reinforcement for crack width control in restrained concrete members considering the deformation compatibility", Structural Concrete, 16(2): pp 221-232, 2015.

20. H. Sasano, I. Maruyama, A. Nakamura, Y. Yamamoto, M. Teshigawara, "Impact of Drying on Structural Performance of Reinforced Concrete Shear Walls", Journal of Advanced Concrete Technology, 16(5): pp 210232, 2018.

21. ACI Committee, "Effect of Restraint, Volume Change, and Reinforcement on Cracking of Mass Concrete", ACI Manual of Concrete Practice, 2002.

\section{LIST OF FIGURES AND TABLES:}

Fig. 1. Restraint and residual stresses in a: a) wall, b) slab foundation; c) the thermal-shrinkage stresses (TS) as the sum of restraint and self-equilibrating residual stresses

Rys. 1. Wymuszone i własne naprężenia w: a) ścianie, b) płycie fundamentowej, c) naprężenia TermicznoSkurczowe (TS) jako suma naprężeń wymuszonych i własnych

Fig. 2. Residual and restraint stresses a) just before and b) just after cracking.

Rys. 2. Własne i wymuszone naprężenia a) zaraz przed i b) zaraz po zarysowaniu

Fig. 3. Relationship between the average stress and the average strain in RC element under axial tension Rys. 3. Średnie naprężenie w zależności od średniego odkształcenia w żelbetowym elemencie rozciąganym

Fig. 4. a) The effective cross-sectional area in thick elements and b) the coefficient $k$, according to [6]

Rys. 4. a) Efektywny przekrój betonowy w grubych elementach oraz b) współczynnik $k$ z [6]

Fig. 5. a) Temperature and b) stress distribution in a RC wall (plate) caused by the cement hydration heat release [1]; c) triangle approximation of residual tensile stress distribution.

Rys. 5.Rozkład a) temperatury i b) naprężeń w żelbetowej ścianie (płycie) spowodowany odpływem ciepła hydratacji cementu [1]; c) trójkątna aproksymacja własnych naprężeń rozciągających

Fig. 6. Determination of a): a drying shrinkage strain in single element under varying ambient conditions;

b) the effective shrinkage strain in two elements casted with the time offset

Rys. 6. Sposób wyznaczania a) odkształceń skurczowych w zmiennych warunkach; b) efektywnych odkształceń skurczowych dla dwóch elementów zabetonowanych w odstępie czasu

Fig. 7. Additional compressive restraint stresses preventing the cracking of the building foundation wall in the second critical term.

Rys. 7. Dodatkowe naprężenia ściskające zapobiegające zarysowaniu ściany na fundamencie budynku w drugim terminie krytycznym

Fig. 8. A retaining wall: a) FEM model description; typical normal stress distribution in: b) short segment, c) long segment, half is shown 
Rys. 8. Ściana oporowa: a) opis modelu MES; typowy rozkład naprężeń w: b) krótkim, c) długim segmencie; pokazano połowę ściany oporowej

Fig. 9. Superposition of restraint and residual stresses for: a) $\sigma_{r t}=0$; b) $\sigma_{r t}>0$; c) $\sigma_{r t}<0 \mathrm{i}\left|\sigma_{r t}\right|<\left|\sigma_{r e s}\right|$, d) $\sigma_{r t}<0 \mathrm{i}\left|\sigma_{r t}\right|>\left|\sigma_{r e s}\right|$; tensile stress is positive

Rys. 9. Superpozycja naprężeń własnych i wymuszonych dla: a) $\sigma_{r t}=0$; b) $\sigma_{r t}>0$; c) $\sigma_{r t}<0 \mathrm{i}\left|\sigma_{r t}\right|<\left|\sigma_{r e s}\right|$,

d) $\sigma_{r t}<0 \mathrm{i}\left|\sigma_{r t}\right|>\left|\sigma_{r e s}\right|$; naprężenia rozciągające są dodatnie

Tab. 1. Design conditions for $\mathbf{m i n}_{c r}$

Tab. 1. Warunki for $\mathbf{m i n}_{c r}$

\section{MINIMUM ZBROJENIA ZE WZGLĘDU NA ZARYSOWANIE W ŻELBETOWYCH ELEMENTACH PODDANYCH ROZCIAGGANIU}

Slowa kluczowe: konstrukcje żelbetowe, minimalne zbrojenie, zarysowanie, szerokość rys, ciepło hydratacji, naprężenia własne i wymuszone

\section{STRESZCZENIE:}

W żelbetowych elementach które nie mogą się swobodnie odkształcać, takich jak ściany na fundamentach i niektóre płyty, na skutek odpływu ciepła hydratacji i skurczu betonu mogą powstać poważne zarysowania. W artykule zwięźle omówiono związany z tymi zjawiskami mechanizm pojawiania się własnych i wymuszonych naprężeń rozciągających. Zdefiniowano dwa krytyczne terminy. W terminie 1, kilka dni po ułożeniu betonu, największe znaczenie mają naprężenia wywołane odpływem ciepła hydratacji. W drugim terminie, który może wystąpić po kilku miesiącach, a nawet latach, podstawową rolę odgrywają naprężenia wymuszone wywołane skurczem betonu.

Do obliczenia zbrojenia potrzebnego ze względu na naprężenia Termiczno-Skurczowe (TS) stosuje się przepisy o minimalnym zbrojeniu ze względu na zarysowanie $\left(\boldsymbol{m i n}_{c r}\right)$. W artykule zaproponowano ulepszoną metodę sprawdzania stanu granicznego zarysowania, polegającą na tym, że przepisy Eurokodu 2 wzbogaca się o uzupełnienia pochodzące z niemieckiego załącznika krajowego. Nie stosuje się uproszczeń (niezbyt zresztą trafnych), polegających na stosowaniu tablic zawartych w Eurokodzie. Projektowanie $\mathbf{m i n}_{c r}$ polega na bezpośrednim obliczaniu szerokości rys powstałych pod wpływem obciążeń rysujących (lub na podstawie uzupełnienia niemieckiego, mniejszych od rysujących) i porównywanie ich z wartością dopuszczalną. Zbrojenie, dla którego szerokość rys jest równa granicznej jest $z$ definicji minimalnym zbrojeniem ze względu na zarysowanie.

Zdefiniowano trzy poziomy analizy. Poziom 0 , w którym obliczenie polega na stosowaniu zgodnych z literą normy (ewentualnie z uzupełnieniami niemieckimi) bardzo prostych obliczeń. Na tym poziomie minimalne zbrojenie nie zależy od kształtu i schematu statycznego elementu i warunków cieplno - wilgotnościowych. Naprężeń TS nie oblicza się. Na poziomie 1 do wyznaczenia naprężeń TS stosuje się proste sposoby oraz MES przy założeniu liniowej sprężystości, co pozwala na zastosowanie powszechnie dostępnych programów komputerowych. Wyniki obliczeń zależą od licznych danych reprezentujących warunki dojrzewania elementu. Metody poziomu 3, które nie są przedmiotem tego artykułu, polegają na stosowaniu zaawansowanych modeli mechanicznych uwzględniających zagadnienia nieliniowe, w szczególności spadek sztywności betonu po zarysowaniu. W artykule umieszczono przykład obliczania minimalnego zbrojenia ze względu na zarysowanie w ścianie oporowej oraz przedyskutowano inne przypadki. 